\title{
THE UNITED STATES, THE EUROPEAN COMMUNITY, AND PROSPECTS FOR A NEW WORLD ECONOMIC ORDER ${ }^{\dagger}$
}

\author{
JOHN M. LEDDY*
}

I

The Beginnings of World Monetary and Trade Reform

In December, I97I, at the Smithsonian Institution in' Washington, the United States, the major governments of Western Europe, Canada, and Japan set the stage for a basic reform of the postwar monetary and trade arrangements established in the International Monetary Fund and the General Agreement on Tariffs and Trade (GATT). The Fund and the GATT, twin instruments of the "world of Bretton Woods," have until now provided the foundation of the liberal economic policies which have contributed greatly to the enormous growth of trade and investment amon'g the countries of the Western world and which have brought their economies to a state of intense interdependence.

The Smithsonian Agreement was the product of crisis rather than of advance planning and deliberative action. The crisis was generated by the sudden and spectacular increase in the balance-of-payments deficit of the United States in early I97r. This was followed by the New Economic Policy of the Nixon Administration in August which, along with the establishment of wage and price controls at home, abandoned the convertibility of the dollar into monetary gold. For good measure, the United States unilaterally imposed a punitive ten per cent surcharge on imports plus an internal tax discrimination against foreign goods as bargaining weapons to force foreign governments into an appreciation of their exchange rates. These blows shook the world trade and monetary system to its foundations. The framework of the world of Bretton Woods, despite its past successes and despite frequent repairs over the years, was clearly unable to cope with the new situation.

The immediate accomplishments of the Smithsonian Agreement were three:

(a) the appreciation of the currencies of other industrialized countries in relation to the dollar of some twelve per cent, accompanied by an increase in' the dollar price of monetary gold from $\$ 35$ to $\$ 38$ per ounce;

(b) a reduction by the European Economic Community and Japan of specified trade barriers to the benefit of United States exports; and

† Originally presented at the Institute on Expansion of the Common Market sponsored by the Duke University School of Law and the Section on International and Comparative Law of the American Bar Association at Duke University on April I4 and 15, 1972. In the fall of 1972 Norway voted against entry into the community. References in the text to the "European Community of Ten" are due to the early preparation of this article.

* Assistant Secretary of State for European Affairs, 1965-1969. 
(c) the suppression by the United States of its newly imposed import surcharge and internal tax discrimination.

The devaluation of the dollar should in itself go a long way toward curing the payments deficit of the United States, given sufficient time and provided-a crucial proviso-that the United States succeeds in its fight against inflation. Also, the trade concessions granted the United States by Japan and the European Economic Community, while of modest dimensions, were nevertheless useful. Those by Japan go far toward removing criticism that Japan has been laggard in living up to its existing GATT commitments to liberalize trade. Those by the European Economic Community, affecting our important exports of grains, tobacco and citrus, at least indicate some disposition on the part of the Community to moderate its highly restrictive agricultural policies and to modify its preferences favoring Mediterranean and African areas. Both the Community's agricultural policies and its free-wheeling with preferences have been subject to sharp attack by the United States in the past and remain as major problems for the future.

But these immediate practical accomplishments of the Smithsonian Agreement, important as they may be, are of far less potential significance than the promise which the Agreement holds for a new and far-reaching cooperative effort by an enlarged European Community, North America, and Japan to strengthen the foundations of the international monetary system and bring about the further liberalization of world trade. In the monetary field, the governments concerned agreed to consider broad-based monetary reform over the long term, including the role of gold, reserve currencies such as the dollar, and "paper gold" or Special Drawing Rights recently invented as a new kind of international reserve asset; the responsibilities of surplus and deficit countries; the volume of liquidity appropriate to the effective working of the system; the question of the flexibility of exchange rates; and measures dealing with the international movement of capital. In the field of international trade, a special declaration was issued by the United States and the European Economic Community in which they "recognized the need for .... a comprehensive review of international economic relations ..." and agreed to "initiate and actively support multilateral and comprehensive negotiations in the framework of GATT beginning in $1973 \ldots$. . with a view to the expansion and the ever-greater liberalization of world trade ...."

The Smithsonian Agreement and its associated understandings ${ }^{1}$ offer hope for 1 The Smithsonian Agreement and its associated understandings consist of the following basic doc-
uments: (I) Press Communique of the Ministerial Meeting of the Group of Ten on 17 th-18th December,
1971 in Washington, D.C., N.Y. Times, Dec. 19, I971, at 56, col. 3; also published as, Sccretary of the
Treasury Connally, Letter to President Nixon Transmitting a Draft Bill "To Provide for a Modification of
the Par Value of the Dollar, and for Other Purposes," Annex 2, February 9, 1972 (pub. by U.S. Treasury
Dept.); (2) Declaration issued by the United States and the European Community together with
exchanges of letters on the results of trade negotiations, N.Y. Times, Feb. 12, 1972, at 1 , col. 2; also
published as a U.S. Treasury Press Release, February II, r972; (3) Joint Statement on International
Economic Relations issued by the United States and Japan on February 9, 1972, together with a descrip- 
the future. If governments follow through on them, "the world of Bretton Woods" can be transformed into the world of today, and the persisting threats of trade and monetary warfare can be dissipated. Crucial to the realization of these hopes will be the continuing relationship between the United States and the European Economic Community, both with its present composition and as it will be enlarged. Without good will and cooperation between these two nothing constructive can be achieved. With these prospects ahead, now is a good time to look at United States relations with the Community as they stand today and as they may develop in the future.

II

The European Economic Community in the Wordd Economic System

Today's European Community of the Six is a partial merger into a single unit of the economies of France, Germany, Italy and the three Benelux countries of Belgium, the Netherlands and Luxembourg. The Six have a complete customs union, with internal free trade and a common external tariff. They have a Common Agricultural Policy, which means a unified system for supporting the incomes of farmers throughout the Community at common prices covering most agricultural output plus common reinforcing measures against imports. They have established complete legal freedom for the movement of labor within the Community with safeguards for the retention of social security rights. Substantial progress has been made toward the free movement of services-for example, the right of businessmen and professionals to establish themselves anywhere in the Community-and toward a common system of value added taxes which make up a significant part of national revenues in the six states. The Community has the beginnings, but only the beginnings, of a common enterprise policy comparable to our own antitrust laws or our own system permitting enterprises incorporated in one state to do business in all others. In addition, it has common, though not comprehensive, programs or policies in the fields of nuclear energy, inland transport, regional development, and manpower. Finally, the Community has its own centralized institutions in Brussels with delicately balanced powers to administer and promote those functions and programs entrusted to the Community, as distinct from the national governments, by the Community's basic constitution, the Treaty of Rome.

The Community's central institutions are genuinely supranational, but within a carefully circumscribed ambit. For example, the Community, and only the Community, can negotiate trade agreements with foreign countries affecting the common external tariff. But if one of the larger members of the Six is determined to block a particular negotiating position favored by the other five, it can certainly do so as a practical matter if not of strict Community law. General de Gaulle proved this more than once.

The major economic area which remains outside the purview of the European

tion of Japanese trade-barrier reductions, N.Y. Times, Feb. ro, 1972, at I, col. 3; also published as a U.S. Treasury Press Release, February II, 1972. 
Community is that of broad monetary and economic policy. Central Banks and national budgets remair in the hands of national governments of the Six as do the accompanying powers over fiscal and monetary policy. There is no Community institution equipped with the authority to deal with foreign monetary officials on behalf of the Six as a whole. The powers to tax and create money, like the powers to raise armies an'd conduct foreign policy, are among the key attributes of a sovereign state. For this reason the Treaty of Rome made no specific provision for a monetary union of the Six. Nevertheless, the Six have recognized that full economic union cannot be achieved without monetary union as well. In' $197 \mathrm{I}$ they launched a plan which, through a series of stages, could result in monetary union, meaning essentially a common Central Bank and a common currency, by 1980 . This is a more ambitious undertaking than any of the Community's past accomplishments, successful as they have been. It is a logical step, and perhaps even a necessary one to maintain the Community's past progress an'd forward momentum. But logic and presumed necessity may not be enough to overcome the formidable political obstacles in the way.

The authors of the Treaty of Rome, whose vision embraced the prospect of an eventual United States of Europe, relied heavily on a working principle which has sometimes been described by the French word engrenage. Literally, engrenage means "meshing" or "gearing." But this does not convey the full sense of what the founders of the European Community had in mind. To analogize their theory-if you get your hands caught in the gears of a powerful machine, all of your body will inexorably be drawn into it. Putting the matter in terms of integration, if one major economic problem is solved by a common action which is virtually irrevocable -for example, the creation of a customs union-that common action will in turn create other problems which can only be solved by further common actions which in turn become irrevocable, and so on. Whether this intriguing principle of engrenage will continue to prove valid for the Community as it approaches the issue of monetary union will be interesting to watch.

The European Community of the Six has already become the world's largest trading entity. With a population of 190 million rivaling our own 200 million, the Community's exports to and imports from the rest of the world are both substantially larger than those of the United States. In I970, for example, Community imports from the rest of the world (excluding intra-Community trade) were over $\$ 46$ billion compared with American imports of $\$ 40$ billion; and Community exports were $\$ 46$ billion compared with United States exports of $\$ 43$ billion. ${ }^{2}$ The Community has attained these high levels of international trade even though its domestic outputits gross national product-is only about half that of the United States, some \$500

\footnotetext{
2 These and other statisties cited have been drawn from the following sources: Organization for Economic Cooperation and Development (OECD) publications; Commssion on Internationat Trade AND INVESTMENT Policy, Report to the President (197I) (GPO); Commission of the European Communities, The Facts, May, r97x (Brussels); U.S. State Department, Buread of Intzlligence and IResearch, Untted States Trade with the EnLarged Europenn Community, I958-7i (April 28, 1972).
} 
billion last year compared with about $\$ 1,000$ billion for the United States. The reason for this, of course, is that the Community's economy is much more closely integrated with the rest of the world than is that of the United States with its vast and varied continental resources. The exports of the Community of Six accounted for nearly ten per cent of total Community economic activity in I970; for the United States the comparable figure was little more than four per cent.

The size and trading power of the Community will be greatly increased with the entry into the Community as full members of the United Kingdom, Ireland, Denmark, and Norway. This event is scheduled to be formalized on January $I$, I973. Thereafter a transitional period will begin for the systematic adaptation of the trade and agricultural arrangements of the four new members to the customs union, common agricultural policies, and other economic programs of the Community, a process that is planned for completion by the end of 1977 .

A rough idea of the size and importance of the new European' Economic Community of Ten can be gained by simply adding together a few statistics for a recent year. Its population of 255 million would be larger than that of the Soviet Union. Its gross national product would be nearly two-thirds that of the United States, nearly thirty per cent greater than that of the Soviet Union and more than two and a half times that of Japan. Its exports of over $\$ 60$ billion would surpass those of the United States by nearly $\$ 20$ billion, and its imports of $\$ 66$ billion would be some $\$ 26$ billion greater than those of the United States.

Needless to say, the commercial policies to be followed by the European Community of Io toward the rest of the world, and the extent to which the United States and the enlarged Community can work constructively together in both the trade and monetary fields will determine the shape of the world economic system of tomorrow. There are latent forces of nationalism and protectionism in both the United States and Europe which could well become strong enough to undo the progress of the past and block further progress toward greater trade liberalization and the strengthening of the international monetary system. Agricultural protectionism is the most obvious example in Europe. At home, the danger is exemplified by the Burke-Hartke bill for broad-scale import restrictions and severe deterrents to American investment abroad, a piece of backward-looking legislation favored by the formerly liberal AFL-CIO.

\section{III}

\section{United States Policy Toward European Unity}

Throughout the postwar period, the United States has strongly supported the goal of European unity. The Marshall Plan, both in concept and execution, gave every encouragement to the "good Europeans" who fathered the Coal and Steel Community of I950, who then tried but failed to achieve political union directly in 1953 through the creation of a common European army and a European Political 
Community, and who eventually, in I957, succeeded in creating the European Economic Community with the signature of the Treaty of Rome.

Perhaps the most eloquent statement of America's policy on European unity was made by President Kennedy, speaking in Frankfurt, Germany, in I963:

[W] have and now look forward to a Europe united and strong-speaking with a common voice-acting with a common will-a world power capable of meeting world problems as a full and equal partner .... .

It is now almost ten years later. The goal of European unity in the fullest sense of the word seems to have receded rather than advanced, and its prospects appear more uncertain than they then appeared. Robert Schaetzel, the present American Ambassador to the Community institutions, remarked in a speech a few months ago that the Kennedy conception of the early rg60's "seems almost impossibly romantic today." He went on to explain that it was not a wrong conception, but that, with our American gift for oversimplification, we had "tended to dismiss too lightly the actual state of European affairs, the enormous effort that remained to be made, the problems and resistance that had to be overcome."

Paradoxically, while the vision of a United States of Europe may have receded, perhaps in part because of our own changing perceptions, the Europe of today is speaking more frequently with a common voice, and a louder one, than ever before, especially on international trade and increasingly on other economic and even political questions as well.

President Nixon took note of the new Europe and its new relationship to the United States in his recent report to Congress on US. Foreign Policy for the 1970's. While reaffirming "emphatically" (his word) America's traditional support for the advancement of European unity, he observed that the change that has taken place within Europe and across the Atlantic "means the end of American tutelage and the end of the era of automatic unity .... The challenge is to find common ground in a consensus of independent policies instead of in deference to American prescriptions. This essential harmony of our purposes is the enduring link between a uniting Europe and the United States. This is why we have always favored European unity and why we welcome its growth not only in geographical area but also into new spheres of policy."

Despite Presidential pronouncements, some Americans will wonder why we supported European unity in the past and why we should welcome its growth and intensification in the future. It is easy to see why a policy of promoting European unity must seem like an anomaly to some of our new revisionist historians. In

\footnotetext{
${ }^{3}$ U.S. Prestent, Public Papers of the Prestdents: John F. KenNedY, I963, 517 (1964).

'U.S. Policy Toward Western Europe-In Transition. Informal remarks by Ambassador J. Robert Schaetzel before the Royal College of Defense Studies, London, November I, 1971. Quoted with the permission of the author.

${ }^{5}$ U.S. Dept. of State, U.S. Foreign Policy for the 1970's-The Emerging Structure of Peace (1972).
} 
their view American foreign policy since the end of World War II has been an imperialist policy of seeking world domination and even of provoling the Cold War for this purpose. America's encouragement of a new and strong power in Western Europe, having its own views and interests, hardly squares with this revisionist interpretation of the behavior of the United States in the postwar period.

But other Americans put the question in terms of immediate self-interest: would America not have been better off without this powerful "discriminatory bloc" as they put it, and why should we continue to encourage it?

The clearest case for the American self-interest in European unity is the political case. First, European unity was seen as the means for putting an end, once and for all, to the national rivalries and hatreds, notably the Franco-German antagonisms, which had so long plagued Western Europe and led to two World Wars. This was a dominant element in the thinking of Robert Schuman; Jean Monnet, and the other "good Europeans" who carried the European Economic Community through to success. It may well be that this objective has already been attained. James Reston in a recent column written from Paris has observed that "there is now such a flow of workers and capital from one Western European country to another, and such a network of international companies gradually integrating the commerce of these nations, that one wonders how the system could ever be disentangled for the purposes of another Western war."6

Second, a united Western Europe, even one with a voice equal to that of the United States and often disagreeing with it on specific issues, was judged to be far more likely to assure world peace under conditions of freedom than a collection of small and medium-sized European states open to coercion and manipulation by a powerful Soviet neighbor hostile to the very foundations of Western society. This appears to remain a valid judgment for the foreseeable future. It should be added, however, that its validity is contingent on the continuing interdependence of Europe and America in the area of common defense, an interdependence given expression through the NATO Alliance. Even those Americans, such as Senator Mansfield, who have been urging the reduction of American troops in West Germany do not question the continuing need for the transatlantic NATO commitment. Nor is there any disposition among the Europeans to see it weaken or disappear.

But what about the economic side? Hasn't the United States paid an economic price as a result of the creation of the Common Market?

The honest answer must be "no" in terms of overall trade and economic relations between the United States and the Community and a qualified "yes" in terms of agricultural trade. Posing the issue more precisely, the question is whether American international trade would have been better off if the Six had retained their separate national customs barriers and agricultural programs instead of creating a huge Common Market to which each of the Six has had free access while maintaining a

'Europe in the Spring, N.Y. Times, Apr. 2, 1972, \$4, at 13, col. I. 
common external tariff and agricultural import levies against the rest of the world. The question is relevant today not because the past can be undone, or should be, but because it may be instructive for the future, especially in the light of the Community's forthcoming enlargement. No one can give an irrefutable answer, but the evidence suggests that the overall trade losses to the outside world arising from the preferred position of each of the Six in the Common Market have been fully offset, or more than offset, by the trade resulting from the remarkable expansion of the European economy to which the formation of the Community clearly contributed. A few statistics will illustrate the point.

-Between 1958 and 1969 , despite gains of over 400 per cent in intraCommunity trade, the Community's imports from the rest of the world increased by $\mathrm{r}_{40} \mathrm{per}$ cent, from $\$ \mathrm{x} 6$ billion to $\$ 39$ billion. This approximates the rate of increase of American imports during the same period, is much higher than import increases in the United Kingdom and Japan, and compares favorably with the import record of all non-Community industrialized countries taken. together.

-American exports to the Community have risen faster than those to the rest of the world. Between $195^{8}$ and 197 r American exports to the Community went up by 192 per cent, compared with $x_{4} 6$ per cent to the world as a whole. -In I971 the United States experienced its first significant trade deficit in the twentieth century, but in trade with the Community we continued to run a surplus, presently about $\$ 900$ million.

American agricultural exports to the Community have done much less well than our total exports, mainly because of the restrictive character of the Community's Common Agricultural Policy. Here our main cause for complaint is not that the Community's policy is common, but that it is restrictive, with high domestic support prices for many products insulated from the world market by variable import levies plus export subsidies disruptive of American agricultural exports elsewhere. Some forty per cent of our agricultural exports to the Community are affected by the Common Agricultural Policy. Even in the case of agriculture, however, the damage to American exports has been less a question of a large absolute reduction of our trade than the instability of the market and the modesty of those export gains we have achieved. The Common Agricultural Policy became fully effective in $x 966$, a year in which American agricultural exports to the Community reached a record level of $\$ \mathrm{r} .6$ billion. In the three succeeding years these exports fell by $\$ 300$ million', recovered in 1970 , and reached a new high of $\$$ 1.8 billion in I971. Thus, the pioture is mixed. What can be said is that for the large portion of our agricultural exports to the Community subject to the Common Agricultural Policy, future markets are unstable. In addition, given the relative efficiency of American agriculture compared with that in Europe, our gains have not been comparable to those for industrial exports. The Community 
remains, nevertheless, the world's largest importer of agricultural commodities and the most important foreign market for American farm exports.

Agricultural protectionism is not unique to the European Economic Community. It is deeply rooted in almost all industrialized countries, not least the United States, which continue to attach high social value to the maintenance of the farm community. The United States has its own domestic price-support an'd other farm aids and has not hesitated to use import quotas and fees whenever necessary to protect them from unwanted imports. Yet, American agriculture, by and large, has a natural comparative advantage over European agriculture, while our domestic support programs are less damaging to trade than theirs. In short, their kettle is blacker than our pot.

A second major quarrel Americans have with the European Economic Community is the Community's practice of concluding preferential trade arrangements with certain foreign countries, not only with African countries which were formerly colonies of European countries, but also with such Mediterranean countries as Spain and Israel. These preferential agreements are perhaps less important for their immediate trade effects than for the threat they pose to the maintenance of a multilateral world trading system.

In monetary affairs, it has been noted that responsibility for monetary policy remains in the hands of national governments rather than in the centralized institutions of the Community. Here the question is whether, in the next few years, steps will be taken toward monetary union among the Community members which would make it more difficult to achieve the reform of the world monetary system. foreshadowed in the Smithsonian Agreement. In a speech before the Council on Foreign Relations, then Secretary of the Treasury Connally addressed this question in the following words:

Does the European Community want to function as a tightly-knit monetary unit, with its members able and willing to renounce independence of action in international monetary affairs? This is a matter for the Europeans to decide. But we cannot escape a close interest in whether monetary unity is a potentially liberalizing and stabilizing force in world financial affairs or will be converted into a vehicle for promoting an inward-looking, defensive bloc. ${ }^{7}$

There may be less here than meets the eye. European monetary union would admittedly avoid future internal disruption of the Common Agricultural Policy, which we have considered "inward-looking," to use Secretary Connally's phrase. Apart from this, however, it is hard to see why the nations of the enlarged Community, with huge amounts of dollars in their monetary reserves and with a stake in the world trading system even larger than that of the United States, would fail to see the benefit of wider cooperation in the interests of an effective international monetary system. Their recent, painful actions to appreciate

${ }^{7}$ U.S. Treasury Department Press Release, March I5, 1972. 
their exchange rates suggest the reverse; and some American financial observers think that European monetary union would tend to strengthen, rather than weaken, the world monetary system as a whole. The Secretary of the Treasury may be concerned that the Europeans will unite behind solutions to monetary problems that are not the preferred solutions of the United States. But, as President Nixon pointed out, the day is past when Americans should expect "allied en'dorsement of American prescriptions." 8

\section{IV}

\section{The Next Steps Toward a New Wordd Economic Order}

The Kennedy Round of tariff negotiations which came into full effect on the first of this year succeeded in substantially reducing the industrial tariffs of the European Community, the United States, and other industrialized countries. According to a recent GATT study, the average industrial tariffs of the Community and the United States are now roughly comparable, the average industrial tariff of the Community of six per cent being somewhat lower than the seven per cent average for the United States. ${ }^{9}$ Little, however, was accomplished in agriculture. Also, the complex network of non-tariff trade barriers existing in all industrialized countries has assumed greater importance than before as tariff levels have come down. Finally, new problems, such as the emergence of the multi-national corporation and the potential impact on world trade of measures designed to improve the environment through anti-pollution standards and the like, may become sources of serious friction in international relations.

In short, the agenda for the future is a heavy one. These are the main items:

I. Reform of the international monetary system. Some of the critical issues under this heading have already been mentioned: flexible versus fixed exchange rates; the role of gold, dollars and paper gold in the world reserve system; the coordination of domestic fiscal and monetary policies; the appropriate responsibilities of both surplus and deficit countries to promote equilibrium.

2. Industrial tariffs. Should the industrialized countries move toward free trade for most industrial goods over the next decade as suggested by the President's Commission on International Trade and Investment Policy?

3. Agricultural trade barriers. Past experience seems conclusive that liberalization of trade in agriculture cannot be realized until governments, including the authorities of the European Community, become willing to accord much greater weight to international considerations in' the formation of their domestic agricultural programs. Our own record with price-support programs reveals the political problems involved.

\footnotetext{
${ }^{8}$ U.S. Foreign POLICY FOR THE I970's, supra note 5.

- Contracting Parties to the General Agreements on Tariffs and Trade (GatT), Bastc Documgentation for Tariff Study (I970).
} 
While progress in this field is not impossible, there is no point in blinking at the difficulties.

4. Non-tariff trade barriers of all kinds, including environmental barriers on the horizon. These barriers are so complex and so variable from country to country and product to product that even the techniques for negotiating about many of them on the basis of mutual advantage and reciprocity are still in the stage of textbook theory. ${ }^{10}$

5. Trade preferences by the European Community. Here the American objective should, at a minimum, seek to prevent their proliferation. If the industrialized countries should go to free trade in in'dustrialized products over a ten year period, a large part of the problem would disappear.

6. Foreign investment and the multi-national corporation. Experts are divided as to whether the multi-national corporation should be subject to some form of intergovernmental control, or at least scrutiny. What seems clear is that the operations of these corporations - one speaks here of their operations in the industrialized countries an'd not of the separate question of investment in the less developed world-have given rise to pressures of a nationalistic and restrictive kind in both the countries receiving the investments and those sending them. If relative freedom of the movement of investment capital is to prevail, at least a declaration of policy to this effect by the European Community, North America and Japan would seem to be in order.

7. The continuing role of international institutions. The institutions which will be the object of future concern include the GAT'T, the Fun'd and its related financial Group of Ten, the Organization for Economic Cooperation and Development, and the bilateral institutional links between the United States and the European Community. The adequacy of all of these needs to be assessed in the light of the new tasks which may have to be performed.

\section{Conclusion}

The Smithsonian understandings were a bare beginning. Whether they become more than that will depend upon the political will of the governments in following them through. So far, the existence of that political will is not persuasively evident. Yet if the objectives which have been declared are not supported by substantive action and negotiation' to accomplish them, we may almost certainly expect to see a deterioration of the existing international economic system and a growing hostility between the United States and the European Community as frictions multiply. One hopes that the tremendous interest of the two in' an expanding world economic system will override growing parochial pressures in the opposite direction and that they will implement the words of the Smithsonian agreements with deeds.

\footnotetext{
${ }^{10} \mathrm{~A}$ good and up-to-date analysis of non-tariff trade barriers can be found in H. Marmaren, International Economic Peacekeeping in Phase II (1972).
} 
The time period for completing negotiations on the scale suggested is not a matter of this year or next. The need for preparation and the hard bargaining involved both suggest that it will be from three to five years, perhaps more, before constructive results can be achieved. Thus, we would be well advised to be patient so long as real forward motion is discernible. 